\title{
Influence of Hot Internet Spot on Laptop User Interest, Learning Motivation and Student Achievement Academic Area (Case Study on Students of Economic Faculty and Islamic Business Iain Kendari)
} Maguni $\mathbf{W}^{1 *}$, Maupa $\mathrm{H}^{2}$ and Asdar $\mathbf{M}^{1}$

${ }^{1}$ Faculty of Economics and Islamic Business at IAIN Kendari - South East Sulawesi, Indonesia

${ }^{2}$ Faculty of Economic Hasanuddin, University South Sulawesi, Indonesia

\begin{abstract}
The formulation of problem in proposal of this research is as follows: significant Internet hot spots on Interest in the use of laptops is there any significant influence of Internet hot spots on learning motivation is there a significant influence of Internet hot spots on student achievement in the academic field Is there a significant influence Interest in laptop usage on learning motivation. Is there a significant influence Interest the use of laptops to student achievement in the academic field? And is there a significant influence on Student Achievement Motivation Achievement in the field of Academic? As for the purpose in this study are as follows:

1. To determine the significant influence of Internet Hot spot to Interest,

2. To know the significant influence of Internet Hot spot on student's achievement in the field of academic,

3. To know the significant influence of laptop usage interest to learning motivation,

4. To know the significant influence of laptop usage interest toward student achievement in field academic

5. To know the significant influence of Student Motivation Achievement in the field of Academic

Based on the research results obtained research results, Hot spot Internet Influence significantly to the interest in the use of laptops, Internet hot spots Influential significantly on learning motivation, Internet hot spots Influential significantly against the achievement of students in the field of academics, Interest in the use of laptops Influence significantly on learning motivation, Interest in the use of laptops Influence significantly on student achievement in the field of academic, Learning Motivation Influence significantly on Student Achievement in Academic field.
\end{abstract}

Keywords: Hot spot internet; Interest; Motivation; Academic achievement

\section{Introduction}

\section{Background}

In the last 5 years the internet usage in the academic community is very fast especially among students of the Faculty of Economics and Islamic Business and generally at IAIN Kendari Student. This internet usage is inseparable from the facilities and infrastructures prepared by Faculty of Economic and Islamic Business of IAIN Kendari, in the form of internet installation network or hot spot which has been installed in the Faculty of Economics and Business (FEBI) of IAIN Kendari and centered on the Mother Installation on IAIN Kendari Rectorate Building which is designed on the use of network system in parallel to every Faculty and Unit in IAIN Kendari environment. With regard to the above mentioned that the phenomenon is visible and can be felt directly to the interest of using a laptop on FEBI IAIN Kendari students in steeped in information, anticipation in doing tasks and interact through social media, and running entrepreneurship business through online business cannot be denied again, and this is starting to become a trend and has been difficult to be separated against the need for internet passivity and media tools to access the internet whether through laptops and smart phones.

More and more students of internet users both through laptops and smart phones, make researchers interested to examine the basic interests of students to facilitate themselves with media or tools to access the internet, and will and will compare with see the effect on student motivation and student achievement in the academic field. So this study will basically see if there is a significant influence between the presence of hot spots, the interest of using the internet through laptops and smart phones as exogenous variables on learning motivation and student academic achievement as endogenous variables. So that the title of this research raised the title of research on "The influence of Hot spot internet on Interest of Laptop Usage, Learning Motivation and Student Achievement in Academic (Study on Student of Faculty of Economics and Islamic Business of IAIN Kendari)".

\section{Scope of problem}

As for the limitations of the problem in the proposal of this study are as follows: Is there a significant influence on the Internet Hot spot, against the Interest of Laptop Usage, Learning Motivation and Student Achievement in the field of Academic

\section{Formulation of the problem}

The formulation of the problem in the proposal of this paper is as follows:

*Corresponding author: Maguni W, Lecturer at the faculty of Economics and Islamic Business at IAIN Kendari - South East Sulawesi, Indonesia, Tel: 6285241504808; E-mail: wmaguni@yahoo.com

Received April 03, 2018; Accepted July 30, 2018; Published August 06, 2018

Citation: Maguni W, Maupa H, Asdar M (2018) Influence of Hot Internet Spot on Laptop User Interest, Learning Motivation and Student Achievement Academic Area (Case Study on Students of Economic Faculty and Islamic Business lain Kendari). Int J Econ Manag Sci 7: 534. doi: 10.4172/2162-6359.1000534

Copyright: $\odot 2018$ Maguni W, et al. This is an open-access article distributed unde the terms of the Creative Commons Attribution License, which permits unrestricted use, distribution, and reproduction in any medium, provided the original author and source are credited. 
Citation: Maguni W, Maupa H, Asdar M (2018) Influence of Hot Internet Spot on Laptop User Interest, Learning Motivation and Student Achievement Academic Area (Case Study on Students of Economic Faculty and Islamic Business lain Kendari). Int J Econ Manag Sci 7: 534. doi: 10.4172/2162-6359.1000534

Page 2 of 7

- Are there any significant influences of Internet hot spots on laptop use Interests?

- Is there a significant influence of Internet hot spots on learning motivation?

- Is there any significant influence of Internet hot spot on student achievement in academic field?

- Is there a significant influence Interest in the use of laptops on learning motivation?

- Is there a significant influence Interest in laptop usage on student achievement in academic field?

- Is there a significant influence on student achievement motivation on academic achievement?

\section{Aim the purpose of this research is as follows}

- To know the significant influence of Internet Hot spots on Interests using laptop,

- To know the significant influence of Internet Hot spot on learning motivation,

- To know the significant influence of Internet Hot spot on student achievement in academic field,

- To know the significant influence Interest in the use of laptop motivation to learn,

- To know the significant effect of the use of laptop interest to student achievement in the academic field,

- To know the significant influence of learning motivation on student achievement in academic field.

\section{Mikrotik Hotspot theory}

The Hotspot or a place that provides Internet access services using wireless is already very much. Ranging from cafes, restaurants, to hotels in general provide wireless Internet service is. This is due to the many devices that have been equipped with wireless technology, so the trend of its use was higher. Unfortunately, not everyone understands how to build Wi-Fi infrastructure. Lack of information and perhaps a rather expensive price make many business owners reluctant to build hotspots. In fact, the existence of this hotspot is potential to increase the attractiveness and also can increase revenue from the place itself.

This article will discuss the important things you need to know to provide hotspot services. The thing discussed is relatively simple so that it can be followed by beginners though (provided it already has the basics of the network). At the end of the article, will also be discussing one tool that is quite practical to use as a hotspot gateway.

- Define your hotspot concept,

- Internet access is quite fast,

- Create a hotspot without billing,

- Create hotspots with billing,

- Configure Internet access.

\section{Interest theory}

Factors affecting interest: As he suggests there are two factors that affect the learning interests of learners, namely:
- The factor from within is the nature of carriage,

- Factors from outside, such as family, school and community or the environment.

According to Crow and Crow cited which mentions that there are three factors underlying the incidence of one's interest:

- Factor of impulse originating from within: These needs can be needs related to the physical and psychological.

- Factors of social motives: The incidence of interest from a person can be driven from social motive of the need to gain respect and the environment in which they are living.

- Emotional factors: This factor is a measure of the intensity of a person in paying attention to a particular activity or object.

According to Johannes, quoted by Bimo Walgito, states that "Interests can be classified into two, namely intrinsic and extrinsic interests. Intrinsic interest is an interest that arises from within the individual himself without outside influences. Extrinsic interest is interest arising from outside influences". Based on this opinion then intrinsic interest can arise because of the influence of attitude. Perceptions, learning achievements, talents, gender and also include work expectations. While extrinsic interest may arise because of the influence of background Socio economic status of parents, parents interest, information, environment and so on. Interest is a tendency to behavior that is oriented to an object, a particular desire or experience, and the tendency between individuals with one another is not as intensive. Individuals can be said to be interested in an object characterized by:

- The tendency to think of objects of interest,

- The desire to pay attention to the object of interest,

- The pleasure of the object of interest,

- The desire to know or follow the object of interest.

\section{Learning motivation theory}

Understanding learning achievement: The word achievement comes from the Dutch language that is prestige. In Big Indonesian Dictionary, learning achievement is the mastery of knowledge or skills developed by the subjects, usually indicated by the value of tests or numbers provided by the teacher.

Buchori defines learning achievement is the result of learning achieved or shown by the students as a result of learning both the numbers or letters and actions that reflect the learning outcomes achieved each in a certain period. Figures or learning outcomes that show the results of learning, thus, the notion of learning achievement is the level of intellectual ability that can be measured, in the form of assignments, knowledge, attitudes and skills as a result of learning.

Indicators of Learning achievement: What students have achieved after learning is often called learning achievement. Achievement of learning achievement or student learning outcomes refers to the aspects of cognitive, affective and psychomotor. Therefore, these three aspects must also be an indicator of learning achievement.

- Type of learning achievement of cognitive field (Ranah Cipta),

- Type of learning achievement affective field (Ranah Rasa),

- Type of learning achievement psychomotor field (Ranah Karsa). 
Citation: Maguni W, Maupa H, Asdar M (2018) Influence of Hot Internet Spot on Laptop User Interest, Learning Motivation and Student Achievement Academic Area (Case Study on Students of Economic Faculty and Islamic Business lain Kendari). Int J Econ Manag Sci 7: 534. doi: $10.4172 / 2162-6359.1000534$

a. Factors Affecting Learning Achievement the factors mentioned include the following:

\section{Internal factor}

- Intelligent factors that include potential factors, namely intelligence and talent as well as factors of real skills, namely the achievements.

- Non-intellective factors are certain personality elements such as attitudes, habits, interests, needs, motivations, emotions and adjustments.

- Physical and psychological maturity factor.

- External factors.

\section{Research Methods}

\section{Types of research}

This study includes the type of survey research, is a study that takes samples from a population and uses questionnaires as a means of collecting basic data. In general, the unit of analysis in this survey research is individual Singarimbun [1]. Therefore, in this study the unit of analysis is Student FEBI IAIN Kendari.

Survey research is used for explanatory or confirmatory explanation that gives explanation of causal relationship between variables through hypothesis submission.

\section{Time and location research}

The study began in January 2017 with location at FEBI IAIN Kendari 3.3.

\section{Population and sample}

Population: The population in this study is 250 students.

Sample: While the sample is part of the number and characteristics possessed by the population Sugiyono [2].

To limit the number of research samples, the authors used Slovin method with the formula:

$$
n=\frac{N}{1+N e^{2}}
$$

$$
\begin{aligned}
& n=\frac{250}{1+250(0.5)^{2}} \\
& n=\frac{250}{251(0.25)} \\
& n=96 .
\end{aligned}
$$

\section{Unit of analysis}

The unit of analysis in this research is FEBI IAIN Kendari students who are considered relevant to obtain adequate data or information in accordance with the issues raised in this research. Prerequisites used to select the sample are active students and study at FEBI IAIN Kendari at least 1 (one) year.

Meanwhile, to limit the number of research samples, the authors used Slovin method with the formula:

$$
n=\frac{N}{1+N e^{2}}
$$

\section{Research design}

The design of this research is as follows (Figure 1):

\section{Data source}

The data sources in this study are:

Primary data: Is the data derived from the questionnaire that has been circulated to the object of research that is Student FEBI IAIN Kendari.

Secondary data: Is the data that can support the primary data that has been taken in the field, for example Student data/semester, Student data based on Prodi in FEBI IAIN Kendari, Student data/force, etc.

\section{Results and Discussion}

In the first indicator that determines the concept of hotspot above shows that as much as $1.0 \%$ of students said strongly disagree, and $14.6 \%$ said doubt, and $31.3 \%$ said agreed and $20.8 \%$ said strongly agree. With this data, it can be understood that the majority of FEBI IAIN Kendari students have benefited from the concept of hotspot in FEBI IAIN Kendari, where they have felt a little more by the existence of

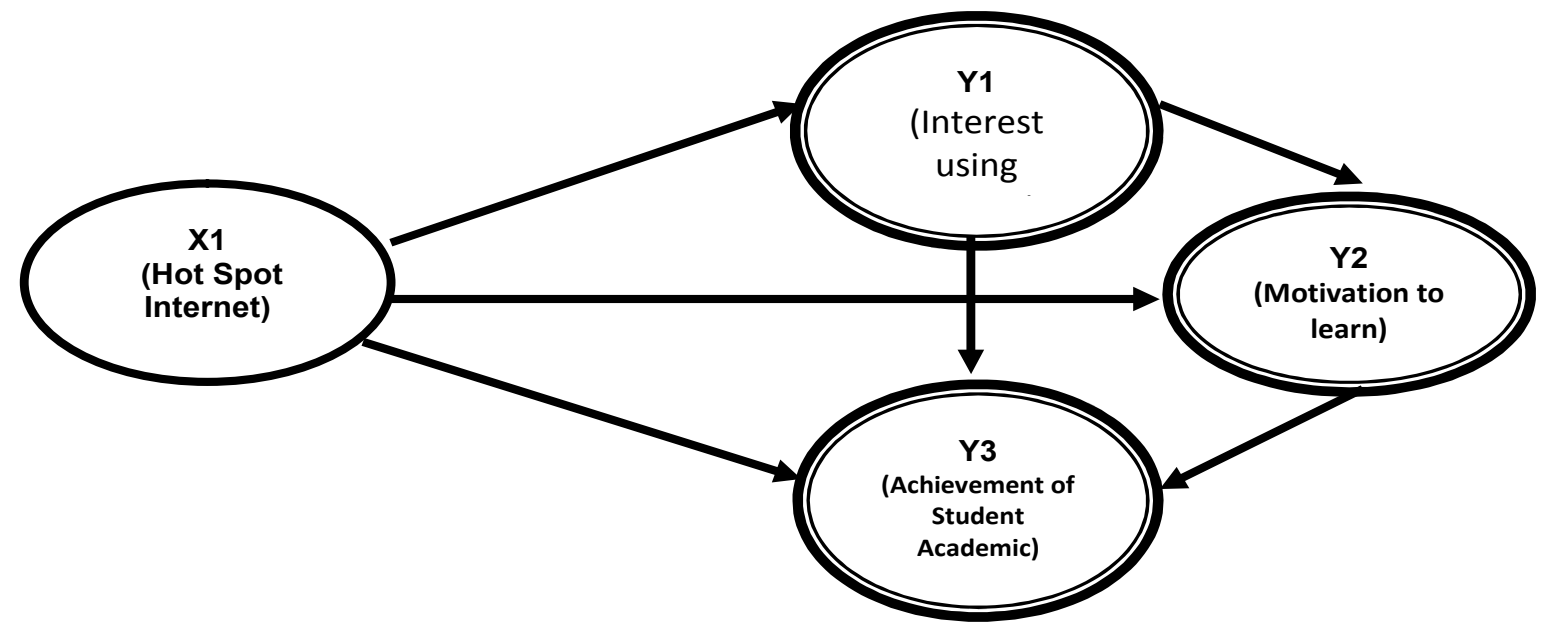

Figure 1: The Influence of Hot spot internet on the Interest of Laptop use, Learning Motivation and Student Achievement of the Academic area. 
Citation: Maguni W, Maupa H, Asdar M (2018) Influence of Hot Internet Spot on Laptop User Interest, Learning Motivation and Student Achievement Academic Area (Case Study on Students of Economic Faculty and Islamic Business lain Kendari). Int J Econ Manag Sci 7: 534. doi: 10.4172/2162-6359.1000534

Page 4 of 7

hotspot concept in Febi IAIN Kendari proven by majority of answers are on Likertt scale 4 (agree) that is equal to $31.3 \%$

In the second indicator of internet access is quite fast, it is known there are $4.2 \%$ say disagree, and there are as many as $19.8 \%$ say hesitant, and there are $22.9 \%$ say agree, and the rest there are $2.1 \%$ said strongly agree, so that from the respondent's answer on the second indicator the majority answered agree that amounted to $22.9 \%$. This can be interpreted that the second indicator is in good category [3].

Next on the third indicator is to create a hotspot without billing or in other words hotspot can be accessed by only $2.1 \%$ there are just say strongly disagree or are on the first Likert scale (1), and there are as many as $10.4 \%$ answer disagree, and there are $22.9 \%$ say hesitant, and $37.5 \%$ say agree and the rest $27.1 \%$ said strongly agree.

Based on the above answer majority of FEBI IAIN students Kendari answer on the Likert scale 4 agree, this means the third indicator is in good category.

In the fourth indicator is the configuration of internet access, or can be interpreted that FEBI IAIN Kendari students have been able to take advantage of internet facilities for academics purposes and seek knowledge of religion and general as well as students also have access to offer on line, and others.

In this indicator there are as many as $2.1 \%$ answered disagree, and there are as many as $8.3 \%$ Febi students answered hesitate or Likert scale 3 , and there are as many as $26.0 \%$ to answer agreed and the rest there are $28.1 \%$ answered strongly agree or Likert scale 5 . This means the fourth indicator (4) the majority of the answers of research respondents or students FEBI IAIN Kendari strongly agree the configuration of internet access in FEBI IAIN Kendari and this also means that the fourth indicator is in good category [4].

The first indicator on the variable Interest Users of Products (laptop) that is the function of usage there are as much as $1.0 \%$ of FEBI IAIN Kendari students who answered not agree, and as many as $8.3 \%$ gave a hesitant answer, and there are as many as $26.0 \%$ answered agree, and there are as many as $14.6 \%$ answered strongly agree. Based on the answers above, the majority of students give answers agree with the function of usability on the interest of laptop users, so it can be explained that FEBI IAIN Kendari students have known and understood the function of the use of laptops and also including smart phones. This also means the first indicator of the variable interest of users of the product (laptop) is in the good category.

Next on the second indicator of interest (intention) there are 2.1\% who declared disagree, and as much as $16.7 \%$ gave a hesitant answer, and as many as $30.2 \%$ agreed to answer, and there are as many as $12.5 \%$ strongly agree. Interest in this indicator can be interpreted that the interest of students in using the laptop is more and more exciting, and this is a positive contribution that the students FEBI IAIN Kendari now has many who have Laptops and smart phones as well. Based on the above data, the majority of FEBI IAIN Kendari students give $30.2 \%$ answer agrees or be on the fourth Likertt scale (4). This means that the variable indicator of interest of laptop user is in good category.

Next on the fourth indicator is attitude (attitude) there are 7.3\% who answered hesitantly, and as many as $40.6 \%$ answered agree, and there are as many as $13.5 \%$ who answered strongly agree, the fourth indicator can be interpreted that students FEBI IAIN Kendari has responded positively with the activity of learn through laptop and laptop facilities owned by the students of the majority to assist in lecturing activities [5].
In the fourth indicator is the attitude (attitude) the majority of students answer FEBI IAIN Kendari is on the scale Likert to 4 is agree that is equal to $40.6 \%$ and afterwards strongly agree as much as $13.5 \%$. This means the fourth indicator is the attitude (attitude) is in good category.

In the first indicator (1) the physiological needs of the Motivation Learning variables, it is known there are as much as $1.0 \%$ of the students FEBI IAIN Kendari gave the answer disagree, and there are as many as $3.1 \%$ give hesitant answers, and as much as $42.7 \%$ give answer agree, and $21.9 \%$ give answer strongly agree.

Based on the results of the overall answers of FEBI IAIN Kendari students, the majority of the answers on the indicator of physiological needs are on the Likert scale 4 or agree, this indicates that the students FEBI IAIN Kendari has made learning through the internet become one of the needs in lectures and students FEBI IAIN agreed to Make the Internet a requirement and a hint to get information, It also means that the indicator is in good category.

Next on the second indicator the need for a feeling of security [6], that there are as many as $1.0 \%$ states disagree, and there are as many as $10.4 \%$ expressed doubt, and there are as many as $42.7 \%$ agreed to answer, and there are as many as $13.5 \%$ give a very agreeable answer. Based on the answers given by FEBI IAIN Kendari students, the majority of the answers are on the Likert scale agreed or (4) that is equal to $42.7 \%$, and subsequently followed by a very agreeable answer of $13.5 \%$.

This means that FEBI IAIN Kendari students have been able to feel a sense of security over the limitations of references and information as well as hotspots through laptops and $\mathrm{hp}$ android has been able to prevent students from lagging information. In addition, this second indicator is in good category. Next on the third indicator of social needs there are $3.1 \%$ states disagree, $20.8 \%$ expressed doubt, and as many as $57.3 \%$ agreed and the remaining $18.8 \%$ stated strongly agree.

Based on the result of analysis, the majority of the answers given by FEBI IAIN Kendari students is on the $4^{\text {th }}$ (fourth) Likert scale or agrees. This means that FEBI IAIN Kendari students have been helped to socialize through the media of laptops and smart phones. So with the third indicator indicator those social needs are in good category [7]. Furthermore, the fourth indicator is the need for self-actualization of learning motivation variables that there are as many as $19.8 \%$ who gave hesitant answers, and as many as $56.3 \%$ gave the answer agreed, and as much as $24.0 \%$ gave the answer strongly agree. Based on the existing answer, that the answer is answerable at the Likert scale of four (4) or agree that is equal to $56.3 \%$, this means that FEBI IAIN Kendari students agree to the presence of hotspot because it can extend friendship and academic and lecture information, and this also means the fourth indicator that the need for self-actualization is in good category. In the first indicator is receiving from learning achievement variable there are as much as $1.0 \%$ states disagree, and there are as many as $22.9 \%$ expressed doubt, and there are as many as $60.4 \%$ answered agree and the rest as much as $15.6 \%$ stated strongly agree [8].

Based on the above data that FEBI IAIN Kendari students receive all forms of learning that lead to improving the quality of learning. And it also shows the first indicator that the receiving is in the good category.

In the second indicator of responding there are as many as $4.2 \%$ on the scale of disagree (2), and as much as $21.9 \%$ expressed doubt, and as many as $59.4 \%$ agreed and there are $14.6 \%$ gave the answer strongly agree. 
Citation: Maguni W, Maupa H, Asdar M (2018) Influence of Hot Internet Spot on Laptop User Interest, Learning Motivation and Student Achievement Academic Area (Case Study on Students of Economic Faculty and Islamic Business lain Kendari). Int J Econ Manag Sci 7: 534. doi: 10.4172/2162-6359.1000534

Page 5 of 7

Based on the data in Table 1, the majority of respondents in this case FEBI IAIN Kendari students agree to the responding in the sense that FEBI IAIN Kendari students have a quick response to what they should do in anticipation that their academic achievement can obtain maximum results.

In the third indicator of Valuing there are as much as $1.0 \%$ states disagree or Likert scale 1 , there are as much as $16.6 \%$ give a hesitant answer or be on the Likert scale 3 , and there are $56.3 \%$ agreed, and the rest of $26.0 \%$ stated strongly agree.

Based on the indicator of the above variable that the majority of students give the answer agree or are on the Likert scale 4, this means that FEBI IAIN Kendari students agree on the indicator variable that is FEBI students Also feel confident with the learning and quick response to the lecturer's direction can accelerate the learning achievement.

Based on the description, the third indicator of valuing can be categorized as good. Next on the fourth indicator of the organization there is as much as $1.0 \%$ on Likert scale to one or strongly disagree, and there are $11.5 \%$ are on the Likert scale 3 (three) or hesitant, and as much as $64.6 \%$ answer agree or Likert scale 4 , and the rest $22.9 \%$ give the answer strongly agree.

Based on the description above that the majority of respondents, in this case FEBI IAIN Kendari students agreed, in the sense that students agree with the facilities provided by FEBI IAIN Kendari students are expected to maximize learning achievement. And this means the fourth indicator is in the good category.

In the fifth indicator, the characteristic is $10.4 \%$ expressing doubt or Likert scale 3 , and as many as $69.8 \%$ give answer agree or be on the Likert scale 4 (four), and the rest $19.8 \%$ stated strongly agree or be on Likert scale 5 .

Based on the above description that the majority of student's answer FEBI IAIN Kendari is on the Likert scale 4 agrees. This means that IAIN Kendari febi students agree if they have responsive characteristics in anticipating the task of their academic duties in order to achieve results in their academic achievement.

\begin{tabular}{|c|c|c|c|c|c|c|}
\hline \multicolumn{7}{|c|}{ Test Value $=0$} \\
\hline & \multirow[t]{2}{*}{$t$} & \multirow[t]{2}{*}{ df } & \multirow[t]{2}{*}{$\begin{array}{c}\text { Sig. } \\
\text { (2-tailed) }\end{array}$} & \multirow[t]{2}{*}{$\begin{array}{c}\text { Mean } \\
\text { Difference }\end{array}$} & \multicolumn{2}{|c|}{$\begin{array}{l}95 \% \text { Confidence } \\
\text { Interval of the } \\
\text { Difference }\end{array}$} \\
\hline & & & & & Lower & Upper \\
\hline $\mathrm{X} 11$ & 38.71 & 95 & 0 & 4.031 & 3.82 & 4.24 \\
\hline $\mathrm{X} 12$ & 56.307 & 95 & 0 & 3.472 & 3.35 & 3.59 \\
\hline $\mathrm{X} 13$ & 35.84 & 95 & 0 & 3.771 & 3.56 & 3.98 \\
\hline $\mathrm{X} 14$ & 57.268 & 95 & 0 & 4.021 & 3.88 & 4.16 \\
\hline Y11 & 68.446 & 95 & 0 & 3.964 & 3.85 & 4.08 \\
\hline $\mathrm{Y} 12$ & 56.573 & 95 & 0 & 3.719 & 3.59 & 3.85 \\
\hline Y13 & 65.769 & 95 & 0 & 3.964 & 3.84 & 4.08 \\
\hline Y21 & 64.262 & 95 & 0 & 4.146 & 4.02 & 4.27 \\
\hline Y22 & 67.091 & 95 & 0 & 3.922 & 3.81 & 4.04 \\
\hline Y23 & 53.253 & 95 & 0 & 3.917 & 3.77 & 4.06 \\
\hline Y24 & 59.676 & 95 & 0 & 4.042 & 3.91 & 4.18 \\
\hline Y31 & 58.868 & 95 & 0 & 3.906 & 3.77 & 4.04 \\
\hline Y32 & 52.624 & 95 & 0 & 3.844 & 3.7 & 3.99 \\
\hline Y33 & 58.314 & 95 & 0 & 4.073 & 3.93 & 4.21 \\
\hline Y34 & 60.654 & 95 & 0 & 4.083 & 3.95 & 4.22 \\
\hline Y35 & 73.677 & 95 & & 4.094 & 3.98 & 4.2 \\
\hline
\end{tabular}

Source: Data Processed Year 2017.

Table 1: One sample test.
From the above mentioned above that characteristic indicator is in good category.

\section{Test of validity}

Validity indicates the extent to which the measuring instrument can measure what is measured. If the measurements have depicted the dimensions and indicators that are relevant or relevant to the concept and its variables, then the instrument has good validity. The validity of an instrument will be observed on the correlation coefficient (r) at a significant level of $5 \%$ or $0,05 \%$. If the correlation coefficient indicates the level of significance or less than $0,05 \%$ then the instrument is considered valid. The results of validity testing instrument research can be seen in Table 1 .

Table 1 shows that all of the indicators of this research variable, both on the exogenous (Hotspot Internet) and endogenous (the theory of the interest of the users of the product (laptop), the learning motivation and the learning achievement have a value of 0.000 or less than 0.05 indicating the instrument used have shown a good level of validity, or are in accordance with what will be measured.

Furthermore, in the following table is one sample table Test, which can be interpreted that serves to determine the value of $t$ of a sample, as well as to determine whether the significant value of the value of $t$, and the research conducted one-sample test on variable $\mathrm{X}$ is Hotspot internet, and Interests user product (laptop) or variable Y1, Y2 Learning Motivation, and Variable achievement learn Y3.

Based on the results of data running SPSS type 21, from research variables consisting of variables X Hotspot Internet, and other variables Y1 variable Interest in product users, and Y2 Motivation Learning variables, and $\mathrm{Y} 3$ variables Learning achievement seen has a positive $t$ value average 57.958, with a positive significant value of 0.000 . It also illustrates that between exogenous variables are the $\mathrm{X}$ variable of the Internet Hot Spot, and Endogenous Variables are Y1 Interest in the Product (laptop), Y2 Learning Motivation, Y3 Learning Achievement has a relationship and mutually positively and significantly affects the significant value at 0.000 .

Furthermore, the following table below shows the different mean of free variable $\mathrm{X}$ variable (Hot spot internet) that is X11 (hotspot determination concept) to the dependent variable $\mathrm{Y}$ consisting of 3 variable Y1 (Interest user of product (laptop)), Y2 (Motivation (Y12), Interests (Y12), Attitude (Y13), Physiological Needs (Y21), Needs for Feelings (Y11), and Y3 (Achievement of Learning) safe (Y22), social needs (Y23), need for self-actualization (Y24), Receiving (Y31), Responding (Y32), Valuing (Y23), Organization (Y24) and Characteristic (Y25) have mean difference) of 3. This means that between the independent variables X11 and the dependent variables $\mathrm{Y} 1, \mathrm{Y} 2$, and $\mathrm{Y} 3$ are not homogeneous.

Furthermore, if we trace further that the standard deviation on variable $\mathrm{X} 11$ to the variables $\mathrm{Y} 1, \mathrm{Y} 2$, and $\mathrm{Y} 3$, all still in the range between 0.3 , and 0.8 . This means that it is still within the limits of reasonableness and can be accepted as a model relationship between free variables and dependent variables.

Furthermore, the next meaning in the following table below shows the different mean of free variable that is $\mathrm{X}$ variable (Hot spot internet) that is X12 (fast enough internet access) to the dependent variable $\mathrm{Y}$ consisting of 3 variable Y1 (Interest of user of product (laptop)), Y2 (Learning Motivation), and Y3 (Achievement of Learning) where the mean that occurs between X12 (determination of hotspot concept to 
Citation: Maguni W, Maupa H, Asdar M (2018) Influence of Hot Internet Spot on Laptop User Interest, Learning Motivation and Student Achievement Academic Area (Case Study on Students of Economic Faculty and Islamic Business lain Kendari). Int J Econ Manag Sci 7: 534. doi: $10.4172 / 2162-6359.1000534$

Page 6 of 7

usability function (Y11), Interests (Y12), Attitude (Y13), physiological needs (Y21), The need for self-actualization (Y24), Receiving (Y31), Responding (Y32), Valuing (Y23), Organization (Y24) and Characteristics (Y25) also have the mean difference of This means that the independent variables X12 and the dependent variables Y1, Y2, and $\mathrm{Y} 3$ are not homogeneous.

Furthermore, if we trace further that the standard deviation on variable $\mathrm{X} 12$ to the variables $\mathrm{Y} 1, \mathrm{Y} 2$, and $\mathrm{Y} 3$, all still in the range between 0.5 , and 0.7 . This means that it is still within the limits of reasonableness and can be accepted as a model relationship between free variables and dependent variables.

In the next meaning in the following table below shows the different mean of the free variable is the $\mathrm{X}$ variable (Hot spot internet) that is X13 (Create Hotspot) to the dependent variable Y consisting of 3 variables Y1 (Interest in the product (laptop)), Y2 ((Y12), Attitude (Y13), Physiological Need (Y21), Needs to be (Y24), Valuing (Y23), Organization (Y24) and Characteristics (Y25) also have an average difference (mean) is also 3. This means that between the independent variable $\mathrm{X} 13$ and the dependent variable $\mathrm{Y} 1, \mathrm{Y} 2$, and $\mathrm{Y} 3$ are not homogeneous. And furthermore, if we further explore that the standard deviation on variable $\mathrm{X} 13$ to the variables $\mathrm{Y} 1, \mathrm{Y} 2$, and $\mathrm{Y} 3$, all still in the range between 0.5 , and 0.7 . This means that it is still within the limits of reasonableness and can be accepted as a model relationship between free variables and dependent variables.

And on the last variable indicator $\mathrm{X}$ on the mean next shows the different mean of the free variable is the $\mathrm{X}$ variable (Internet hot spot) is $\mathrm{X} 14$ (Internet access configuration) to the bound variable $\mathrm{Y}$ consisting of 3 variables Y1 (Interest user (Y12), Interests (Y12), Attitude (Y13), Y2 (Learning Motivation), and Y3 (Achievement of Learning) where the mean that occurs between X14 (hotspot concept determination on function of usefulness (Y11) (Y24), Receiving (Y31), Responding (Y32), Valuing (Y23), Organization (Y24) and Characteristics (Y22), Need for the feeling of security (Y22) Y25) also has a mean difference of 3. This means that between the independent variables X14 and the dependent variables $\mathrm{Y} 1, \mathrm{Y} 2$, and $\mathrm{Y} 3$ are not homogeneous. And further, if we further explore that the standard deviation on the variable X14 to the variables $\mathrm{Y} 1, \mathrm{Y} 2$, and $\mathrm{Y} 3$, all still in the range also between 0.5 , and 0.7. This means that it is still within the limits of reasonableness and can be accepted as a model relationship between free variables and dependent variables.

Furthermore, in the table below the researcher shows the relationship between variable $\mathrm{X}$ (Hot spot Internet) consisting of each indicator that is (determination of concept Hotspot) X11, (internet access fast enough) (X12, (Make Hotspot without Billing) X13, and (Configuring Internet Access) X14 against Variable Y1 (User Interests Products) consisting of indicator variable Y1: namely Y11, Interests and Attitudes (Y13), based on the results if the data has a positive and significant effect, as can be seen in the correlation table between variables is variable $\mathrm{X}$ to variable $\mathrm{Y} 1$.

Furthermore, in the table below the researcher shows the relationship between variable $\mathrm{X}$ (Hot spot Internet) consisting of each indicator that is (determination of concept Hotspot) X11, (internet access fast enough) (X12, (Make Hotspot Without Billing) X13, and (Configuring Internet Access) X14 to Variable Y2 (Learning Motivation) consisting of Y2 variable indicator: namely (Physiological Requirement) Y21, (Need for Safety) Y22, and Social Needs (Y23), and (Need for Self-actualization) Y24. Based on the results if the data have a positive and significant influence, as can be seen in the correlation table relationship between variables i.e. variable $\mathrm{X}$ against variable $\mathrm{Y} 2$ Furthermore, in the table below the researcher shows the relationship between variable $\mathrm{X}$ (Hot spot Internet) which consists of each indicator that is (determination of Hotspot concept) X11, (internet access fast enough) X12, (Create Hotspot Without Billing) X13, and (Configuration internet access) X14 to Variable Y3 (Achievement learn) consisting of indicator variable Y3: that is (Receiving) Y31, (Responding) Y32, and (Valuing) Y33, and (Organization) Y34. Based on the results if the data has a positive and significant influence, as it can be seen in the correlation table, relationship between variables i.e. variable $\mathrm{X}$ is against variable $\mathrm{Y} 3$.

Furthermore, in the table, the researcher shows the relationship between Y1 variable (Interest Users of Products (laptop0) consisting of each indicator that is (Y11 usefulness function, Y11, Attention) Variable Y2 (Motivation learn) consisting of indicator variable Y2: that is (Physiological Need Y21, (need a sense of security) Y22, and (Social need) Y23, and (Need for self-actualization) Y24 Based on result of data also have influence which is positive and significant, as can be seen in the correlation table of relationships between variables i.e., variable $\mathrm{Y} 1$ to variable $\mathrm{Y} 2$.

Furthermore, in the Table 1, the researcher shows the relationship between the Y1 variable (Interest of the Product User (laptop) consisting of each indicator that is (usefulness function) Y11, (Interests) Y12, (Attitude) Y13, to Y3 variable (Achievement learn) consisting of indicator variable Y3: that is (Receiving) Y31, (Responding) Y32, and (Valuing) Y33, and (Organization) Y34.Based on result if data have positive and significant influence, can be seen in table correlation relationship between variables i.e. variable Y1 to variable Y3.

Furthermore, in the Table 1, the researcher shows the relationship between Y2 variable (Motivation Learning) consisting of each indicator that is (physiological requirement) Y21, (Need for feeling secure) Y22, (Social Needs) Y23, (Need for Self-actualization) Y24 Variable Y3 (Achievement learn) which consist of indicator variable Y3: that is (Receiving) Y31, (Responding) Y32, and (Valuing) Y33, and (Organization) Y34. Based on the results if the data have a positive and significant influence, as can be seen in the correlation table relationship between variables i.e. variable $\mathrm{Y} 1$ to variable $\mathrm{Y} 3$.

\section{Conclusions and Recommendations}

The conclusions in this study are as follows:

- Internet hot spots significant impact on interest in laptop usage,

- Internet hot spots Influence significantly on learning motivation,

- Hot spot Internet Influence significantly on the achievement of students in the academic field,

- Interest in the use of laptops Influential significantly on the motivation to learn,

- Interest in the use of laptops Influence significantly on student achievement in the academic field,

- Learning Motivation Influence significantly on Student Achievement in the field of Academic.

- Still need to increase Power Hot Internet spot in Febi IAIN Kendari so that students can more easily access internet,

- With the Hot spot Internet can increase the interest of students in using laptops and smart phones to support activities academic, 
Citation: Maguni W, Maupa H, Asdar M (2018) Influence of Hot Internet Spot on Laptop User Interest, Learning Motivation and Student Achievement Academic Area (Case Study on Students of Economic Faculty and Islamic Business lain Kendari). Int J Econ Manag Sci 7: 534. doi: $10.4172 / 2162-6359.1000534$

- With Internet Hotspot can further improve the academic achievement of FEBI IAIN Kendari students.

\section{References}

1. Singarimbun (2011) Survey Research Methods, Publisher: LP3ES Library, Jakarta.

2. Sugiyono (2008) Qualitative Research Methods Quantitative and R\&D, Publisher Alfabeta, Bandung.

3. Purwanto N (2007) Educational Psychology. Bandung: PT Remaja Rosdakarya.
4. Nasution S (1987) Various Approaches in the Teaching and Learning Process. Jakarta: Bina Aksara.

5. Suryabrata S (1981) Consumer Interest, Publisher: PT. Teens, Rosda works, Diknas, Bandung

6. Suryabrata S (2002) Educational Psychology. Jakarta: PT. Raja Grafindo Persada, Indonesia.

7. Winkel WS (1997) Guidance and Counselling in Educational Institutions Jakarta: Gramedia Widia-Sarana Indonesia.

8. Sudrajat A (2008) Theories-Motivation Theory. 